\title{
Short communication: Effects of prepartum diets supplemented with rolled oilseeds on Brix values and fatty acid profile of colostrum
}

\author{
R. Salehi, ${ }^{*}$ D. J. Ambrose, ${ }^{*} \dagger$ and M. Oba*1 \\ *Department of Agricultural, Food and Nutritional Science, University of Alberta, Edmonton, Alberta, T6G 2P5, Canada \\ †Livestock Research Branch, Alberta Agriculture and Rural Development, Edmonton, Alberta, T6H 5T6, Canada.
}

\begin{abstract}
The objective of this study was to evaluate effects of oilseeds supplemented in prepartum diets on colostrum quality. Thirty-nine dry pregnant Holstein cows (14 primiparous and 25 multiparous cows) were blocked by body condition score and parity and assigned to 1 of 3 experimental diets containing rolled oilseeds at $8 \%$ of dietary dry matter (canola seed or sunflower seed) or no oilseed (control) at $35 \mathrm{~d}$ before the expected calving date. Canola seed is high in oleic acid and sunflower seed is high in linoleic acid content. Colostrum samples were collected at the first milking after calving, and concentrations of nutrient composition, fatty acid profile, and Brix value (an indicator IgG concentration) were determined. Cows fed sunflower seeds before calving produced colostrum with greater crude protein content (15.0 vs. $12.9 \%$ ), colostral Brix values (24.3 vs. $20.3 \%$ ), and conjugated linoleic acid concentration (18:2 cis-9,trans-11; 0.64 vs. $0.48 \%)$ compared with those fed canola seed. Positive effects of feeding sunflower seed might be mediated by ruminal metabolism of linoleic acid and subsequent enhanced production of conjugated linoleic acid. Oilseed supplementation in prepartum diets of dairy cows also altered fatty acid profile of colostrum in a way to reflect fatty acid profile of the supplemented oilseeds except for oleic acid. In conclusion, prepartum feeding of sunflower seed increased colostral Brix value, an indicator of colostral IgG concentration, compared with that of canola seed, but its mode of action and effects on health and productivity of calves need to be investigated.
\end{abstract}

Key words: colostrum, sunflower seed, canola seed, fatty acid profile, Brix

\section{Short Communication}

Elevated blood fatty acid concentration and accumulation of lipids in the liver during the periparturient

Received July 31, 2015.

Accepted November 24, 2015.

${ }^{1}$ Corresponding author: moba@ualberta.ca period exert significant effects on health and milk production of dairy cows (Drackley, 1999). Prepartum fat supplementation was proposed as a nutritional strategy to prime cows for fat mobilization during the periparturient period and to reduce accumulation of lipids in the liver. In the literature, prepartum fat supplementation decreased plasma fatty acid concentration (Andersen et al., 2008; Ballou et al., 2009), plasma BHB concentration (Ballou et al., 2009; Damgaard et al., 2013), and liver triglyceride accumulation (Grum et al., 1996; Andersen et al., 2008; Damgaard et al., 2013) during the periparturient period. However, positive effects of prepartum fat supplementation on health and productivity of dairy cows have not been consistent and sometimes have been detrimental (Duske et al., 2009; Karimian et al., 2015), and its efficacy is still controversial. Although cows have been the primary research focus in those recent studies evaluating effects of prepartum fat supplementation, it is also expected to affect colostrum composition, fatty acid profile, and possibly IgG concentration. However, little data exist on the effects of prepartum nutritional management on colostrum quality. As such, the objective of the current study was to evaluate effects of prepartum supplementation of oilseeds differing in fatty acid profile on colostrum quality.

The animal study was conducted at the Dairy Research Unit of the University of Alberta, Edmonton, and all animal experimental procedures were according to the guidelines of the Canadian Council on Animal Care (2009; Ottawa, Ontario, Canada) and approved by the University of Alberta Animal Care and Use Committee for Livestock.

Thirty-nine nonlactating pregnant Holstein cows (14 primiparous and 25 multiparous cows), a subset of animals from a larger study (Salehi et al., 2016), were used. Cows were blocked by BCS and parity, and assigned to 1 of 3 experimental diets containing rolled oilseeds at $8 \%$ of dietary DM (canola seed or sunflower seed) or no oilseed (control) at $35 \mathrm{~d}$ before the expected calving date (Table 1). Canola seed is high in oleic acid and sunflower seed is high in linoleic acid content (Salehi et al., 2016). Cows were housed individually in tiestalls, fed once daily at $0800 \mathrm{~h}$, and had unrestricted access to 
water. Diets were offered ad libitum as a TMR. Detailed experimental diets and experimental procedures are described in the companion paper (Salehi et al., 2016). Colostrum samples were collected at the first milking after calving, and analyzed for concentrations of fat, $\mathrm{CP}$, and lactose by infrared spectroscopy (MilkoScan 605; Foss Electric, Hillerød, Denmark; AOAC International, 2002) at the Central Milk Testing Laboratory (Edmonton, Alberta, Canada). A Brix refractometer (Atago Co., Ltd., Tokyo, Japan) was used to estimate concentration of IgG (Bielmann et al., 2010; Quigley et al., 2013). Colostrum samples were also analyzed for fatty acids profile. Fatty acids in colostrum samples were extracted as described by Folch et al. (1957). The fatty acid profile of extracted lipids was assessed by gas chromatography as previously described by CruzHernandez et al. (2007).

Data were analyzed using the MIXED procedure of SAS (version 9.3, 2011; SAS Institute Inc., Cary, $\mathrm{NC}$ ) and means were compared using orthogonal contrasts to test the effects of prepartum oilseed (oilseed vs. no oilseed control) and type of oilseed (canola vs. sunflower) supplementation. The statistical model included prepartum dietary treatment and parity as the main effects and the interaction of prepartum dietary treatment by parity when it was significant. All data are reported as mean \pm standard errors; significance was declared at $P \leq 0.05$, whereas $P>0.05$ but $\leq 0.10$ was considered trends.

Cows fed sunflower seeds before calving produced colostrum with higher CP content (15.0 vs. 12.9\%; $P=0.05)$ and greater colostral Brix values (24.3 vs. $20.3 \% ; P<0.01$; Table 2), an indicator of colostral IgG concentration, compared with those fed canola seed. Colostral IgG concentration was not measured directly, but estimated from Brix values in the current study. It has been shown that the Brix readings are highly correlated with $\operatorname{IgG}$ concentration determined by radial immunodiffusion assay (Bielmann et al., 2010), and the colostral Brix reading of $21 \%$ is used to identify colostrum with IgG concentration of $50 \mathrm{~g} / \mathrm{L}$ or greater (Quigley et al., 2013). Estimated colostral IgG concentrations (estimated using the equation: -61.896 $+5.666 \times$ Brix \%; Quigley et al., 2013) were 58.2, 53.1 , and $75.8 \mathrm{~g} / \mathrm{L}$, respectively for control, canola, and sunflower treatments.

Sunflower seed, which increased colostral Brix values, is greater in linoleic acid concentration than canola seed (Salehi et al., 2016). In agreement with our findings, Lessard et al. (2004) reported that feeding a prepartum diet containing micronized soybean, which is high in linoleic acid, increased colostral antibody responses to ovalbumin challenge compared with diets containing whole flaxseed or calcium salts of palm oil. Greater
Table 1. Ingredients and nutrient composition of prepartum experimental diets

\begin{tabular}{|c|c|c|c|}
\hline \multirow[b]{2}{*}{ Item } & \multicolumn{3}{|c|}{ Prepartum dietary treatment } \\
\hline & Control & Canola & Sunflower \\
\hline \multicolumn{4}{|l|}{ Ingredients, $\%$ of DM } \\
\hline Barley silage & 60.0 & 60.0 & 60.0 \\
\hline Alfalfa hay & 10.0 & 10.0 & 10.0 \\
\hline Ground barley grain & 10.0 & 10.0 & 10.0 \\
\hline Soybean hulls & 10.0 & 6.2 & 3.4 \\
\hline Canola meal & 5.0 & 0.8 & 3.6 \\
\hline Canola seed & 0.0 & 8.0 & 0.0 \\
\hline Sunflower seed & 0.0 & 0.0 & 8.0 \\
\hline Vitamins and minerals & 5.0 & 5.0 & 5.0 \\
\hline \multicolumn{4}{|c|}{$\begin{array}{l}\text { Nutrient composition, \% of DM } \\
\text { (unless otherwise noted) }\end{array}$} \\
\hline $\mathrm{CP}$ & 14.2 & 13.8 & 14.4 \\
\hline NDF & 42.0 & 41.3 & 40.1 \\
\hline Starch & 11.6 & 10.0 & 9.8 \\
\hline Ether extracts & 2.7 & 7.4 & 6.2 \\
\hline $\mathrm{NE}_{\mathrm{L}}, \mathrm{Mcal} / \mathrm{kg}$ & 1.40 & 1.61 & 1.55 \\
\hline
\end{tabular}

${ }^{1}$ Adapted from Salehi et al. (2016).

antibody responses to linoleic acid feeding may be mediated by CLA. The positive effects of feeding CLA on serum IgG concentration were documented for rats $(\mathrm{Su}-$ gano et al., 1998), pigs (Corino et al., 2001), and goats (Castro et al., 2006). Furthermore, Corino et al. (2009) reported that feeding CLA beginning $7 \mathrm{~d}$ before parturition increased colostral IgG concentration in sows, and speculated that CLA is involved in production of interleukins, which regulate immunoglobulin synthesis.

Griinari and Bauman (1999) showed that CLA in ruminant milk derives from incomplete biohydrogenation of linoleic acid in the rumen, either directly or indirectly via absorption of 18:1 trans-11 followed by desaturation to 18:2 cis-9,trans-11 (Griinari et al., 2000). We found that sunflower seed treatment increased concentration of 18:2 cis-9,trans-11 in colostrum compared with canola seed treatment (0.64 vs. $0.48 \% ; P=0.02)$. Our findings, along with evidence in the literature, collectively indicated that prepartum feeding of sunflower seed increased CLA production, and possibly led to enhanced IgG concentration in colostrum estimated by Brix values. However, Garcia et al. (2014) recently reported that feeding SFA (Energy Booster 100; Milk Specialties, Dundee, IL) during the late gestation period decreased CLA concentration in colostrum, but increased colostral IgG concentration of parous dairy cows compared with Ca salts of fatty acids (Megalac-R; Church \& Dwight, Princeton, NJ). Reasons for the discrepancies are not known, and the possible role of CLA in colostral IgG production warrants further investigation. Future studies should determine colostrum yield as well as IgG concentration to quantify IgG production accurately. 
In the current study, we also found that prepartum supplementation of oilseeds decreased fat content of colostrum in primiparous cows, but not in multiparous cows. We found an interaction effect between treatment and parity on DMI, in which oilseed supplementation did not affect DMI of primiparous cows whereas it decreased DMI of multiparous cows (Salehi et al., 2016). However, oilseed treatments increased plasma fatty acid concentration at $3 \mathrm{wk}$ before calving and $1 \mathrm{wk}$ after calving to a similar extent for both multiparous and primiparous cows (Salehi et al., 2016). As such, it is not known why prepartum oilseed supplementation decreased fat concentration of colostrum only in primiparous cows.

Prepartum oilseed supplementation increased the proportion of stearic acid (11.3 vs. $7.65 \% ; P<0.0001)$, linoleic acid (3.63 vs. 2.89\%; $P<0.001$ ), and linolenic acids ( 0.54 vs. $0.46 \% ; P=0.03)$ in the colostrum compared with control, but did not affect oleic acid concentration. These findings were consistent with the report of Santschi et al. (2009) and Garcia et al. (2014), where supplementation of linseed or Energy Booster (Milk Specialties) or Megalac-R (Church \& Dwight) during the transition period was evaluated, respectively. It is noteworthy that prepartum fat supplementation did not affect oleic acid concentration of colostrum consistently whereas it affected concentrations of other long-chain fatty acids. Cows fed sunflower seed had greater proportions of medium- and short-chain fatty acids $(<\mathrm{C} 18$; 55.3 vs. $48.8 \% ; P=0.01)$ and linoleic acid (4.05 vs. $3.21 \% ; P<0.01)$, but lower proportions of stearic acid
(9.89 vs. $12.7 \% ; P<0.01$ ), oleic acid (primiparous cows only; 20.5 vs. $26.3 \% ; P<0.0001$ ), and linolenic acid (0.49 vs. $0.59 \% ; P=0.02$ ) in the colostrum compared with those fed canola seed before calving. In general, the fatty acid profile of colostrum reflected the fatty acid profile of oilseeds supplemented in prepartum diets (Salehi et al., 2016). Type of oilseed supplemented in the current study affected fatty acid profile of colostrum to a greater extent than that reported by Garcia et al. (2014) possibly because dietary fat content was greater in our study than that of Garcia et al. (2014). These findings collectively suggest that the fatty acid profile of colostrum is easily affected by the amount and type of fat supplemented in prepartum diets. However, little data exists in the literature on how colostral fatty acid profile affects health and productivity of calves.

In conclusion, prepartum feeding of sunflower seed increased colostral Brix value, an indicator of colostral IgG concentration, compared with feeding canola seed. As sunflower seed contains more linoleic acids than canola seed, we inferred that feeding sunflower seed increased endogenous CLA production, which may have increased colostral IgG concentration. In addition, our findings suggest that the fatty acid profile of colostrum, except for oleic acid, reflects the fatty acid profile of oilseeds supplemented in prepartum diets.

\section{ACKNOWLEDGMENTS}

This study was supported by Alberta Livestock and Meat Agency (Alberta, AB, Canada), Alberta

Table 2. Effects of prepartum dietary treatment on colostrum composition (means $\pm \mathrm{SE}$ )

\begin{tabular}{|c|c|c|c|c|c|}
\hline \multirow[b]{2}{*}{ Item } & \multicolumn{3}{|c|}{ Prepartum dietary treatment } & \multicolumn{2}{|c|}{$P$-value } \\
\hline & Control & Canola & Sunflower & $\begin{array}{l}\text { Fat vs. } \\
\text { control }\end{array}$ & $\begin{array}{c}\text { Canola vs. } \\
\text { sunflower }\end{array}$ \\
\hline Primiparous cows, no. & 4 & 4 & 6 & - & - \\
\hline Multiparous cows, no. & 9 & 9 & 7 & - & - \\
\hline Brix, $\%^{1}$ & $21.2 \pm 0.92$ & $20.3 \pm 0.96$ & $24.3 \pm 0.88$ & 0.29 & $<0.01$ \\
\hline \multicolumn{6}{|l|}{ Fat, $\%^{2}$} \\
\hline Primiparous cows & $7.08 \pm 0.77$ & $4.79 \pm 0.77$ & $3.46 \pm 0.70$ & $<0.01$ & 0.21 \\
\hline Multiparous cows & $3.82 \pm 0.50$ & $3.30 \pm 0.57$ & $4.00 \pm 0.52$ & 0.79 & 0.37 \\
\hline $\mathrm{CP}, \%$ & $12.7 \pm 0.66$ & $12.9 \pm 0.69$ & $15.0 \pm 0.63$ & 0.09 & 0.05 \\
\hline Lactose, \% & $3.04 \pm 0.10$ & $3.14 \pm 0.11$ & $2.85 \pm 0.10$ & 0.48 & 0.07 \\
\hline \multicolumn{6}{|c|}{ Fatty acid profile, $\mathrm{g} / 100 \mathrm{~g}$ of total fatty acids } \\
\hline$<\mathrm{C} 18$ & $58.6 \pm 1.75$ & $48.8 \pm 1.75$ & $55.3 \pm 1.75$ & $<0.01$ & 0.01 \\
\hline C18:0 & $7.35 \pm 0.63$ & $12.7 \pm 0.63$ & $9.89 \pm 0.63$ & $<0.0001$ & $<0.01$ \\
\hline \multicolumn{6}{|l|}{$\mathrm{C} 18: 1^{2}$} \\
\hline Primiparous cows & $22.5 \pm 1.36$ & $26.3 \pm 1.36$ & $20.5 \pm 1.11$ & 0.53 & $<0.0001$ \\
\hline Multiparous cows & $16.5 \pm 0.91$ & $24.5 \pm 0.91$ & $22.5 \pm 1.03$ & 0.13 & 0.99 \\
\hline C18:2 & $2.89 \pm 0.14$ & $3.21 \pm 0.14$ & $4.05 \pm 0.14$ & $<0.001$ & $<0.01$ \\
\hline $\mathrm{C} 18: 2$ cis-9,trans-11 & $0.39 \pm 0.04$ & $0.48 \pm 0.04$ & $0.64 \pm 0.04$ & $<0.01$ & 0.02 \\
\hline C18:3 & $0.46 \pm 0.03$ & $0.59 \pm 0.03$ & $0.49 \pm 0.03$ & 0.03 & 0.02 \\
\hline$>\mathrm{C} 18$ & $1.70 \pm 0.14$ & $2.07 \pm 0.14$ & $1.85 \pm 0.14$ & 0.16 & 0.28 \\
\hline
\end{tabular}

${ }^{1}$ Colostral Brix reading.

${ }^{2}$ Treatment by parity interaction was significant $(P<0.05)$. 
Innovates - BioSolutions (Edmonton, AB, Canada), Alberta Milk (Edmonton, AB, Canada), and Livestock Research Branch, Alberta Agriculture and Rural Development (Edmonton, AB, Canada). The authors thank A. Ruiz-Sanchez (University of Alberta, Edmonton, $\mathrm{AB}$, Canada) for technical assistance.

\section{REFERENCES}

Andersen, J. B., C. Ridder, and T. Larsen. 2008. Priming the cow for mobilization in the periparturient period: effects of supplementing the dry cow with saturated fat or linseed. J. Dairy Sci. 91:10291043.

AOAC International. 2002. Official Methods of Analysis. 17th ed. AOAC International, Gaithersburg, MD.

Ballou, M. A., R. C. Gomes, S. O. Juchem, and E. J. DePeters. 2009. Effects of dietary supplemental fish oil during the peripartum period on blood metabolites and hepatic fatty acid compositions and total triacylglycerol concentrations of multiparous Holstein cows. J. Dairy Sci. 92:657-669.

Bielmann, V., J. Gillan, N. R. Perkins, A. L. Skidmore, S. Godden, and K. E. Leslie. 2010. An evaluation of Brix refractometry instruments for measurement of colostrum quality in dairy cattle. J. Dairy Sci. 93:3713-3721.

Canadian Council on Animal Care. 2009. CCAC guidelines on: The care and use of farm animals in research, teaching and testing. CCAC, Ottawa, ON, Canada.

Castro, N., J. Capote, D. Martin, and A. Arguello. 2006. The influence of dietary conjugated linoleic acid on blood serum and colostrum immunoglobulin $\mathrm{G}$ concentration in female goats before and after parturition. J. Anim. Physiol. Anim. Nutr. (Berl.) 90:429-431.

Corino, C., V. Bontempo, and D. Sciannimanico. 2001. Effect of dietary conjugated linoleic acid on some aspecific immune parameters and acute phase protein in weaned piglets. Can. J. Anim. Sci. 82:115-117.

Corino, C., G. Pastorelli, F. Rosi, V. Bontempo, and R. Rossi. 2009. Effect of dietary conjugated linoleic acid supplementation in sows on performance and immunoglobulin concentration in piglets. J. Anim. Sci. 87:2299-2305.

Cruz-Hernandez, C., J. K. G. Kramer, J. J. Kennelly, D. R. Glimm, B. M. Sorensen, E. K. Okine, L. A. Goonewardene, and R. J. Weselake. 2007. Evaluating the conjugated linoleic acid and trans 18:1 isomers in milk fat of dairy cows fed increasing amounts of sunflower oil and a constant level of fish oil. J. Dairy Sci. 90:3786-3801.

Damgaard, B. M., M. R. Weisbjerg, and T. Larsen. 2013. Priming the cow for lactation by rapeseed supplementation in the dry period. J. Dairy Sci. 96:3652-3661.

Drackley, J. K. 1999. Biology of dairy cows during the transition period: The final frontier? J. Dairy Sci. 82:2259-2273.
Duske, K., H. M. Hammon, A. K. Langhof, O. Bellmann, B. Losand, K. Nürnberg, G. Nürnberg, H. Sauerwein, H. M. Seyfert, and C. C. Metges. 2009. Metabolism and lactation performance in dairy cows fed a diet containing rumen-protected fat during the last twelve weeks of gestation. J. Dairy Sci. 92:1670-1684.

Folch, J., M. Lees, and G. H. Sloane Stanley. 1957. A simple method for the isolation and purification of total lipides from animal tissues. J. Biol. Chem. 226:497-509.

Garcia, M., L. F. Greco, M. G. Favoreto, R. S. Marsola, L. T. Martins, R. S. Bisinotto, J. H. Shin, A. L. Lock, E. Block, W. W. Thatcher, J. E. P. Santos, and C. R. Staples. 2014. Effect of supplementing fat to pregnant nonlactating cows on colostral fatty acid profile and passive immunity of the newborn calf. J. Dairy Sci. 97:392405.

Griinari, J. M., and D. E. Bauman. 1999. Biosynthesis of conjugated linoleic acid and its incorporation into meat and milk in ruminants. Pages 180-200 in Advances in Conjugated Linoleic Acid Research, vol. 1. M. P. Yurawecz, M. M. Mossoba, J. K. G. Kramer, M. W. Pariza, and G. J. Nelson, ed. AOCS Press Champaign, IL.

Griinari, J. M., B. A. Corl, S. H. Lacy, P. Y. Chouinard, K. V. V. Nurmela, and D. E. Bauman. 2000. Conjugated linoleic acids is synthesized endogenously in lactating dairy cows by $\Delta^{9}$-desaturase. J. Nutr. 130:2285-2291.

Grum, D. E., J. K. Drackley, R. S. Younker, D. W. LaCount, and J. J. Veenhuizen. 1996. Nutrition during the dry period and hepatic lipid metabolism of periparturient dairy cows. J. Dairy Sci. 79:1850-1864.

Karimian, M., M. Khorvash, M. A. Forouzmand, M. Alikhani, H. R. Rahmani, M. H. Ghaffari, and H. V. Petit. 2015. Effect of prepartal and postpartal dietary fat level on performance and plasma concentration of metabolites in transition dairy cows. J. Dairy Sci. $98: 330-337$.

Lessard, M., N. Gagnon, D. L. Godson, and H. V. Petit. 2004. Influence of parturition and diets enriched in n- 3 or n- 6 polyunsaturated fatty acids on immune response of dairy cows during the transition period. J. Dairy Sci. 87:2197-2210.

Quigley, J. D., A. Lago, C. Chapman, P. Erickson, and J. Polo. 2013. Evaluation of the Brix refractometer to estimate immunoglobulin G concentration in bovine colostrum. J. Dairy Sci. 96:1148-1155.

Salehi, R., M. G. Colazo, M. Oba, and D. J. Ambrose. 2016. Effects of prepartum diets supplemented with rolled oilseeds on calf birth weight, postpartum health, productive and reproductive performance of dairy cows. J. Dairy Sci. 99:3584-3597. http://dx.doi. org $/ 10.3168 /$ jds.2015-10186.

Santschi, D. E., H.-R. Wettstein, F. Leiber, A.-K. M. Witschi, and M. Kreuzer. 2009. Colostrum and milk fatty acids of dairy cows as influenced by extruded linseed supplementation during the transition period. Can. J. Anim. Sci. 89:383-392.

Sugano, M., A. Tsujita, M. Yamasaki, M. Noguchi, and K. Yamada. 1998. Conjugated linoleic acid modulates tissue levels of chemical mediators and immunoglobulins in rats. Lipids 33:521-527. 